\title{
The Inevitability of Colin's Death in The Comfort of Strangers
}

\author{
Yafen Huang, Ruimin Xu \\ Nanchang Institute of Science \& Technology, Nanchang 330108, China
}

Keywords: The Comfort of Strangers; psychoanalysis; family systems theory; inevitability; Colin's death

\begin{abstract}
McEwan's book, The Comfort of Strangers, is all the more disturbing, because it leaves many questions without definitive answers. This paper explores one of questions that why Colin, but not Mary is killed. In terms of four characters, Robert in particular is analyzed by psychoanalysis and their relationships, especially relationship between Colin and Mary based on family systems theory, and it can be concluded that the Colin's death is not contingent but inescapable.
\end{abstract}

\section{Introduction}

Ian McEwan is the post-modern British author of eight novels, several collections of short stories, plays, screenplays, and an oratorio. He has been critically rewarded for several of his works, and The Comfort of Strangers won the Booker Prize in 1981. The bizarre and unsettling novel relates a horrifying story. Mary is a divorced mum of two children, and Colin is a handsome bachelor. They are an unmarried couple, returning to an unnamed city in an attempt to rekindle their romance and repair the fissures in their stale relationship. A seemingly fortuitous encounter with the aristocratic Robert bemuses them. Robert takes them to his bar, entertains them with wine and tells perverted tales of his childhood. Too drunk to find their way home, the couple spends the night in the street. The next morning, Robert spots them and insists they come to his house to catch some sleep and join him for supper. In his magnificent museum-like palazzo, they meet his wife Caroline, who seems sexually masochistic and in control of her husband. Despite obvious signs that this is a peculiar couple, Mary and Colin are seemingly mesmerized by them, finding themselves inexplicably back at the Robert's villa and drawn into a dark world of sexuality and murder, while Robert and Mary are spiders, twitching their net, waiting for the right victims to come along. At Mary and Colin, they pounce. In the end, Colin is drawn to his destiny like moths to flames. He is brutally killed by Robert. After finishing reading the novel, since it is set in the background of patriarchal society, most readers will raise a question: why is Colin, but not Mary, killed? Then the article will untie the knot in reader's mind in terms of four characters and the relationship between them to prove that Colin's death is inevitable.

\section{Accounts for the Inevitability of Colin's Death in Terms of Perpetrators}

Firstly, the inevitability will be explored from Robert's childhood experience. Robert's story is about an oppressive and controlling father and several sisters who resent their brother's role as flunky in a highly-sexed household. "Everybody was afraid of him. My mother, my four sisters, even the ambassador was afraid of my father. When he frowned nobody could speak. At the dining-table you could not speak unless spoken to first by my father" ${ }^{[1]}$ indicates Robert's upbringing in the male-dominated atmosphere. However, Robert as the next head of the family fails to maintain masculinity and has the feminized self, as his eating of the chocolate can be regarded as a giving up of his masculinity in favor of behaving like a "weak-willed girl" "2]. Moreover, a psychoanalytic reading of the novel foregrounds Robert's negotiation of feminization and patriarchy. According to Freud's theory, the levels of consciousness can be divided into the conscious, the preconscious and the unconscious. The unconscious means that it is transformed into conscious material, only comes about with a considerable expenditure of energy, or may never occur at all. 
One key factor in the operation of the unconscious is repression. Freud believes that many people repress painful memories deep into their unconscious mind. So the fact that he is severely punished by his father is deeply rooted in his mind, it is the femininity that make Robert despise in himself and Robert's obsession with his father remains with him throughout his life. Unfortunately, Colin's lack of male dominance and being Robert's feminized self, as pointed out in Mary's physical description of him while he is sleeping, will undoubtedly incur Robert's hatred. "McEwan demonstrates that Robert's need to inflict violence on Colin is no more than a substitute for his father's infliction of violence on him" ${ }^{[3]}$. He is compelled, therefore, to imitate his father as punisher, by destroying the effeminate Colin. It is reasonable to say that his final act is driven by his unconscious. "In 'punishing' Colin, he is able at last to step into his father's shoes and punish his failed, effeminate self once and for all” ${ }^{[2]}$. Moreover, his conscious motivate him to destroy Colin, who is representative of the gender confusion that undermines patriarchal culture. Secondly, the perverted relationship between Robert and Caroline should be responsible for the inevitability of Colin's death. His father's demand to control and dominate becomes corrupted in Robert, so he hopes to be a dominator in his life, and his desires are played out in sexual abuse. Consequently, Robert's behaviors become even more perverse and inhuman when he makes love with Caroline: "He used a whip. He beat me with his fists as he made love to me" ${ }^{11]}$. However, Caroline readily and willingly accepts her husband's domination: "We both liked what was happening. I was ashamed of myself, and before I knew it, my shame too was a source of pleasure. It was as if I was discovering something that had been with me all my life. I wanted it more and more. I needed it" "1]. She tells Mary love means that "If you are in love with someone, you would even be prepared to let them kill you, if necessary" "1]. She has also been tainted by her husband's patriarchal attitudes when she clarifies her statement: "if I was the man I would (kill the person I'm in love with)" [1]. Finally, such sado-masochistic relationship will stimulate their insatiable longings, and for being incapable of satisfying each other, they must prey upon Colin. On the other hand, Colin and his behavior are on many occasions linked explicitly and implicitly to that of a baby or a child: "He caught up with her in skipping steps" "1]. "Colin touched Mary's breasts, she turned and kissed first his lips and then, in a tender, motherly way, his nose" ${ }^{[1]}$. "His arms were crossed foetally over his chest...the feet, abnormally small like a child's, pointing inwards...His buttocks were small and firm, like a child's" [1] "Robert adopted the tone of one who explains the self-obvious to a child" [1]. So there clearly is the suggestion that Colin is Mary's child rather than her partner. Robert jealously "punishes" Mary (the parent that he himself is prevented from being) by murdering her "child" "4]. According to the novel, Robert can't become a father for something wrong with his sperm. Furthermore, in Robert's view, a true man should assert his masculinity by siring children, sons in particular. Mary often talks and thinks about her children, whereas Colin is not too keen on discussing the topic and he is prone to be childless, which adds to Robert's contempt for him.

\section{Accounts for the Inevitability of Colin's Death in Terms of Victims}

Why Robert focuses on Colin and kills him not Mary at last should attribute to feminism displayed by Mary. She is a feminist, delighted to see a poster in the street calling for the castration of rapists, and when Mary talks about her children, her feminism exposes obviously and she is proud of them. "Her ten-year-old daughter had finally been selected for the school football team, and had been so savagely tackled by the boys in her first two matches that she had had to spend a week in bed. Then she cut her hair for the next match to avoid persecution and had even scored a goal” ${ }^{[1]}$. It is exactly this obvious feminism that challenges the Robert's patriarchal system and thus makes Robert's displacement of his disgust with her onto Colin. Counter-intuitively, Robert attacks the man, rather than the woman who represents what he despises. On the other hand, the family systems theory suggests that individuals cannot be understood in isolation from one another, but rather as a part of their family, as the family is an emotional unit. Families are systems of interconnected and interdependent individuals, none of whom can be understood in isolation from the system. Unlike conventional psychological theory which focuses on the individual, Family Systems Theory encourages people to think of issues in terms of a multigenerational family or a 
"system." This approach encourages people to move away from blaming others and towards individual responsibility. In the context of systems theory, the paradigm of a successful family system is one that encourages and allows its members to develop into independent, well-differentiated individuals, who choose to affiliate themselves with others in constructive, complementary, and open support systems. In contrast, a poorly differentiated individual will develop out of a family that organizes itself around a maladaptive desire to maintain a protective closed system in which members become enmeshed with each other, and unable to function successfully as independent beings ${ }^{[3]}$. As for Colin and Mary, as McEwan implies, the capability of building genuine intimacy and connection may be unachievable. Therefore, rather than providing an opportunity for healthy differentiation, Robert strains the tensions within Colin and Mary's enmeshed dyad to the point of implosion instead.

Once more Mary leaned against Colin's shoulder. 'You're going to have to look after me today.' She spoke through a yawn.

He stroked the nape of her neck. 'Did you look after me yesterday, then?'

She nodded and closed her eyes. The demand to be looked after was routine between them, and they took it in turns to respond dutifully ${ }^{[1]}$.

Family Systems Theory recognizes such behavior as indicative of the lack of differentiation within each of the members of this dyad. Concomitant to a decrease in differentiation, individuals become less independently functional and more reliant on the relationship for their sense of well-being. For Colin and Mary, the boundaries between them as individuals have dissolved to the extent that now they only really understand themselves as a unit, as is indicated by their "preoccupation with whether they have gotten enough or given enough in the relationship" [5]. They are in contrast to another couple, Robert and Caroline, whose intimacy is much fiercer and deeper than Colin and Mary's, but whose connection has been transformed into madness and violence. So their shallow intimacy cannot withstand the pressures from an outside intrusion. Furthermore, Colin and Mary also prove to be incompetent tourists, failing to tour the place without proficiency. Always forgetting their maps, they continually become lost in the labyrinthine roadways. Even once they are forced to sleep in the street because they are unable to find their hotel. Because of their incompetence, they find themselves totally dependent upon the maid. "Rapidly, however, they came to depend on her and grew lazy with their possessions. They became incapable of looking after one another, incapable, in this heat, of plumping their own pillows, or of bending down to retrieve a dropped towel" ${ }^{11]}$. This dependence upon others ultimately leads to their destruction. Moreover, they also form a habit of inertia, passivity and aimlessness. Occasionally, they do tour the city, walking past shops and looking for restaurants without any purpose or passion. They often propose to go somewhere, to do something, but then remain motionless. For instance, when Mary suggests that they leave for the restaurant, "Colin agreed, but neither moved" [1] " "Let's walk to the hotel.'But neither of them stirred” "1] and “"we should turn our faces,'Mary said, but they continued to watch as he came closer" ${ }^{\text {[1] }}$. All these provide a good opportunity for Robert's intrusion into their superficially intimate relationship. Although it seems that their relationship becomes closer after returning from Robert's villa, however, for Colin and Mary, this renewed connection is inauthentic, not based on true affectionate desire. "Throughout the day, even when all subjects and all desire were momentarily exhausted, they stayed close, sometimes stifled by the very warmth of the other's body, but unable to break away for a minute, as though they feared that solitude, private thoughts, would destroy what they shared" ${ }^{[1]}$. So their shallow intimacy and loose relationship will have them enmeshed in Robert's trap, and at last result in their destruction as well as Colin's tragedy.

\section{Conclusion}

The inevitability of Colin's death insinuates itself throughout the whole novel. It is not hard for readers to find clues with their insightful eyes and exploring spirits. Thus, the inevitability will present itself vividly before readers. For example, Robert's childhood experience, his 
sado-masochistic relationship with Caroline, Mary's feminism, her shallow intimacy and loose relationship with Colin, etc. All these hint the Colin's tragedy that his death is inevitable.

\section{References}

[1] McEwan, Ian. The Comfort of Strangers[M]. London: Jonathan Cape Ltd,1981.

[2] Seaboyer, Judith. “Sadism Demands a Story: Ian McEwan's The Comfort of Strangers.” Modern Fiction Studies[M]. 45.4 (Winter 1999): 957-86. Reproduced in Contemporary Literary Criticism. Galenet: Gale Literary Database. Gale Group. Drew University Library. 18 February 2004 $<$ http: II galenet.gale.com>.

[3] Hennessey, colleen M. A SACRED SITE: FAMILY IN THE NOVELS OF IAN MCEWAN[J]. Drew University, 2004. Ann Arbor: UMI, 2004.3146388.

[4] Forceville Charles. The Metaphor “COLON IS A CHILD” in Ian McEwan's, Harold Pinter's and Paul Schrader's The Comfort of Strangers[J]. Amsterdam: Department of Literature Vrije University, 1999.

[5] Keer, Michael, and Murray Bowen. Family Evaluation: An Approach Based on Bowen Theory[M]. New York: Norton, 1988. 